\title{
PERSEPSI MASYARAKAT TERHADAP KERUSAKAN LINGKUNGAN AKIBAT PENAMBANGAN TIMAH DI KECAMATAN KOBA, KABUPATEN BANGKA TENGAH
}

\section{Agung Ferianda}

aferianda@gmail.com

Program Studi Ilmu Administrasi Negara

Sekolah Tinggi Ilmu Sosial Politik Pahlawan 12 Bangka

\begin{abstract}
ABSTRAK
Bangka island is the biggest Tin Mining centre at Indonesia, bt this mining activity effect to environment damage. Because of that, this research head for study the society to environment damage as consequence of Tin mining activity. Research method that use is survey. Respondent in this research are family head at Nibung village. Berok Village and Simpang Perlang village. The sum of respondent is 90 family heads. Variable that use in this research are dependent variable and independent variable. Dependent variable that is perception and independent variable are education, knowledge, occupation, income, sum of consist of qualitative descriptive analysis and quantitative analysis with helping of SPSS Program. In entire whole society perception about environment damage because of tin mining: $42 \%$ belong to low perception category, $47 \%$ belong to medium perception category, and $11 \%$ belong to high category. Factor that most effecting to society perception is knowledge factor.
\end{abstract}

Pulau Bangka merupakan pusat pertambangan timah terbesar di Indonesia. Kegiatan penambangan tersebut berakibat pada kerusakan lingkungan. Penelitian ini bertujuan untuk mengkaji persepsi masyarakat terhadap kerusakan lingkungan akibat kegiatan penambangan timah. Metode penelitian yang digunakan adalah metode survei. Responden dalam penelitian ini adalah kepala keluarga di Desa Nibung, Kelurahan Berok dan Kelurahan Simpang Perlang. Jumlah responden sebanyak 90 kepala keluarga. Variabel yang digunakan dalam penelitian ini adalah variabel dependen dan variabel independen. Variabel dependen adalah persepsi, sedangkan variabel independent berupa pendidikan, pengetahuan, pekerjaan, pendapatan, jumlah anggota rumah tangga, dan daerah asal. Dalam penelitian ini teknik yang digunakan adalah teknik analisis deskriptif kualitatif dan analisis kuantitatif dengan bantuan program SPSS. Secara keseluruhan persepsi masyarakat terhadap kerusakan lingkungan akibat penambangan timah: $42 \%$ termasuk kategori persepsi rendah, $47 \%$ kategori persepsi sedang, dan $11 \%$ kategori persepsi tinggi. Faktor yang paling berpengaruh terhadap persepsi masyarakat tersebut adalah faktor pengetahuan.

Kata kunci: Persepsi Masyarakat, Penambangan Timah, Kerusakan Lingkungan

\section{PENDAHULUAN}

Sektor penambangan mempunyai peranan yang penting dalam pembangunan Kabupaten Bangka Tengah, khususnya Kecamatan Koba, dikarenakan sumber daya mineral yang terbilang cukup banyak. Dengan melihat sejarah, dapat diketahui betapa besar peranan pertambangan timah bagi masyarakat Kepulauan Bangka Belitung. Akan tetapi, seiring dengan meningkatnya jumlah penduduk, pemanfaatan sumber daya mineral-dalam hal ini biji timah-semakin meningkat pula yang lambat laun mengakibatkan habisnya sumber daya mineral tersebut. Yang kemudian nyata-nyata ditinggalkan adalah lingkungan yang rusak akibat kegiatan penambangan tersebut.

Kegiatan penambangan memang selalu berkaitan erat dengan masalah kerusakan lingkungan yang ditimbulkannya. Hasil dari penambangan tersebut memang tidak dapat dimungkiri dapat meningkatkan perekonomian masyarakat khususnya, dan perekonomian daerah pada umumnya. Akan tetapi, menjaga kelestarian lingkungan akan lebih penting pula untuk persediaan bagi generasi mendatang dan juga 
mencegah bencana alam akibat dari kerusakan lingkungan yang ditimbulkan oleh adanya kegiatan penambangan. Oleh karena itu, peran serta masyarakat dalam kepentingan ini sangatlah diperlukan.

Setelah penambangan timah berhenti, lokasi bekas penambangan timah akan ditinggalkan atau dibiarkan begitu saja oleh para penambang. Selang beberapa waktu kemudian dilakukanlah kegiatan reklamasi untuk mengembalikan kondisi alami tanah. Akan tetapi, upaya reklamasi itu sering terkendala oleh minimnya tanah untuk menimbun kembali karena sudah hanyut terbawa air, kurangnya biaya reklamasi, serta teknologi maupun kurangnya kesadaran kalangan penambang. Walaupun mengembalikan kondisi alami tanah secara utuh sebagaimana sebelum ditambang itu tidaklah mungkin, upaya pemulihan dan pemanfaatan lokasi bekas penambangan timah untuk berbagai keperluan yang ekonomis haruslah tetap dijalankan. Hal ini bertujuan agar tidak timbul kerusakan yang semakin luas.

Peran serta masyarakat dalam upaya penanggulangan kerusakan lingkungan yang terjadi akibat kegiatan penambangan timah sangat ditentukan oleh seberapa besar tingkat pengetahuan masyarakat tentang kegiatan penambangan, baik terkait dengan manfaat yang bisa diterima dari kegiatan penambangan tersebut, dampak yang ditimbulkan dari kegiatan penambangan tersebut, maupun pengetahuan arti penting kelestarian lingkungan. Dari tingkat pengetahuan masyarakat tersebut, bisa diketahui bagaimana persepsi masyarakat terhadap kerusakan lingkungan yang terjadi, serta faktor-faktor dominan yang mempengaruhi persepsi masyarakat. Dari sini baru bisa kita ketahui peran serta atau partisipasi masyarakat dalam menanggulangi kerusakan lingkungan yang terjadi.

\section{KERANGKA TEORI Persepsi}

Secara umum persepsi dapat dibedakan menjadi dua jenis, yaitu persepsi personal dan persepsi sosial (masyarakat). Persepsi personal adalah proses berpikir seseorang sehingga mampu memberikan penafsiran khusus terhadap situasi tertentu (Luthan, 1981, dalam Ritohardoyo, 1995). Person perception adalah suatu proses pembentukan kesan berdasarkan pengamatan ataupun penalaran terhadap suatu hal yang mempunyai pengaruh pada fisik maupun psikologik (Harvey dan Smith, 1977, dalam Ritohardoyo, 2006). Persepsi masyarakat adalah suatu proses pembentukan kesan, pendapat, ataupun perasaan terhadap sesuatu hal yang melibatkan penggunaan informasi secara terarah (Secord dan Backman, 1964, dalam Ritohardoyo, 2006). Dengan demikian, persepsi bersifat sangat subjektif karena sangat bergantung pada perseptor atau orang yang berpersepsi.

Persepsi mempunyai implikasi yang sangat penting terhadap tatanan perilaku, termasuk tatanan perilaku sosial yang mempengaruhi hidup dan kehidupan lingkungan sosial (social system) maupun lingkungan biogeofisik (ecosystem). Menurut Sutami (dalam Ritohardoyo, 2006) yang mengatakan bahwa sistem sosial dan ekosistem merupakan dwitunggal yang tidak dapat dipisahkan antara satu dengan yang lain. Masing-masing mencangkup satuan fungsional yang merupakan suatu interaksi kehidupan dengan lingkungannya. Jika objek persepsi seseorang terhadap lingkungan mempunyai nilai positif mampu mempengaruhi perseptor, baik secara fisik maupun psikologik, maka pada gilirannya dapat memberikan motivasi tatanan perilaku masyarakat yang positif pula terhadap lingkungannya.

\section{Kerusakan Lingkungan}

Kerusakan lingkungan adalah pengaruh sampingan dari tindakan manusia untuk mencapai suatu tujuan yang mempunyai konsekuensi terhadap lingkungan (Hardjasoemantri,1997). Menurut Soemarwoto (2001), untuk mengatasi proses kerusakan lingkungan perlu dikembangkan sumber daya manusia pengelola lingkungan yang andal. Syarat utama untuk keandalan sumber daya manusia itu adalah sadar lingkungan dengan berpandangan holistik, serta sadar hukum dan mempunyai komitmen terhadap lingkungan. Masyarakat merupakan pengelola lingkungan sehingga masingmasing individu dalam masyarakat adalah pengelola lingkungan. Pemahaman atas hal ini tidak banyak yang disadari oleh anggota masyarakat. Jika kita dapat menyadarkan masyarakat bahwa mereka mempunyai kewajiban untuk mengelola lingkungan dengan baik, sebagaimana tertera dalam Undangundang No. 4 Tahun 2006 tentang Ketentuan Pokok-pokok Pengelolaan Lingkungan Hidup, kita akan mencapai kemajuan yang besar dalam pengelolaan lingkungan. Menyertakan masyarakat secara aktif dalam kegiatan pengelolaan lingkungan menjadi syarat mutlak keberhasilan usaha yang dilakukan. 


\section{Perilaku Manusia}

Perilaku muncul sebagai akibat dari adanya interaksi antara stimulus dan organisme. Bandura (dalam Bimo Walgito, 1999: 14) mengemukakan suatu formulasi mengenai perilaku, dan sekaligus dapat memberikan informasi bagaimana peran perilaku itu terhadap lingkungan dan terhadap individu atau organisme yang bersangkutan. Formulasi Bandura secara lengkap dapat dilihat seperti tertera di bawah ini:
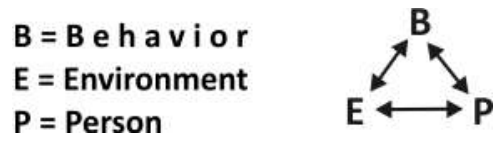

Perilaku, Lingkungan, dan Individu (Person) itu sendiri saling berinteraksi satu dengan yang lain. Ini berarti bahwa perilaku individu dapat mempengaruhi individu itu sendiri. Selain itu, perilaku juga berpengaruh pada lingkungan, demikian pula lingkungan dapat mempengaruhi individu; demikian pula sebaliknya.

Ada tiga faktor yang mempengaruhi perilaku manusia, yaitu faktor dasar, faktor pendukung dan faktor pendorong. Faktor dasar misalnya adat istiadat, pandangan hidup, dan kepercayaan. Faktor pendukung berupa pendidikan, pekerjaan, strata sosial dan budaya. Faktor pendorong misalnya media massa, penyuluhan tokoh agama dan tokoh masyarakat. Ketiga faktor membentuk perilaku manusia yang selanjutnya melahirkan persepsi, baik persepsi kejiwaan, mental, maupun persepsi intelektual. Persepsi juga melahirkan tatanan perilaku positif dan negatif serta lingkungan sosial di kelompok masyarakat. Tatanan perilaku itu, baik positif maupun negatif, selanjutnya membentuk lingkungan hidup manusia. Secara lengkap dapat dilihat pada gambar 1. Sejauh mana penyerapan informasi oleh seseorang tergantung dimensi kejiwaan dan persepsi terhadap lingkungan, yang untuk selanjutnya akan direfleksikan pada tatanan perilakunya.

Pada dasarnya perilaku adalah refleksi potensi faktor pendukung yang terdapat di dalam jiwa setiap individu untuk bereaksi terhadap lingkungannya beserta segala isinya (Ritohardoyo, 2006). Dalam hal ini perilaku akan bereaksi terhadap sesama manusia, tumbuhan, hewan, benda mati lainnya, juga bereaksi terhadap konsep-konsep tertentu. Meskipun bersifat individual, perilaku dalam kehidupan bermasyarakat dipengaruhi oleh unsur fisik individu, keadaan jiwa dan norma-norma ataupun konsep-konsep kehidupan yang berlaku di lingkungannya.

\section{Gambar 1: Skema hubungan faktor-faktor yang berpengaruh terhadap perilaku manusia}

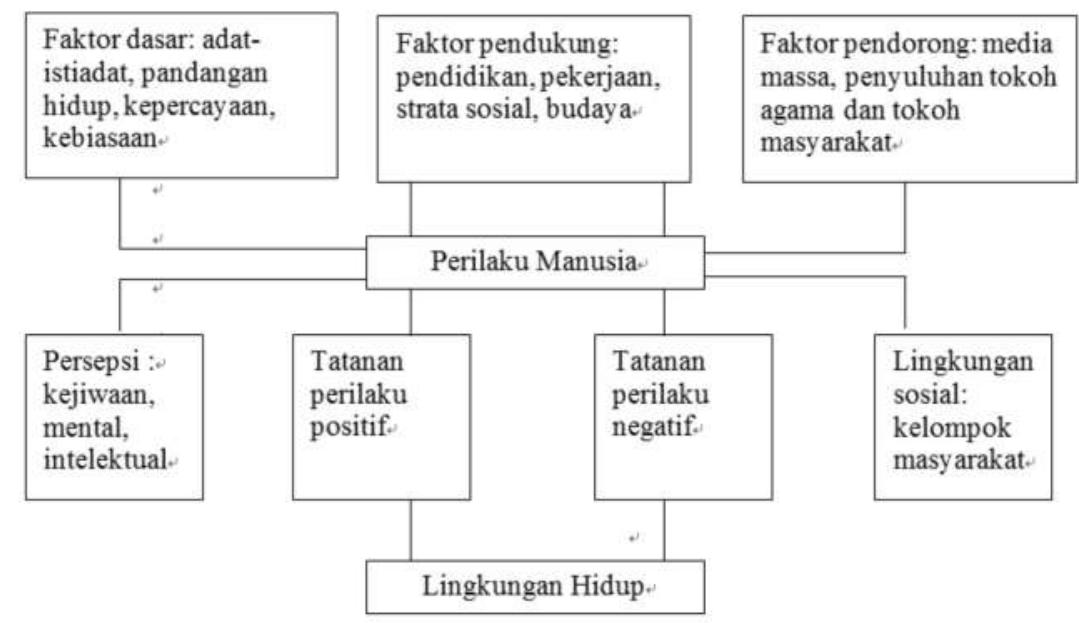

\section{METODOLOGI PENELITIAN}

Jenis Penelitian

Metode penelitian yang digunakan adalah metode survei dengan variabel yang digunakan dalam penelitian ini berupa variabel dependen dan variabel independen. Variabel dependen adalah berupa persepsi, sedangkan variabel independen berupa pendidikan, pengetahuan, pekerjaan, pendapatan, jumlah anggota rumah tangga, dan daerah asal. Dalam penelitian ini, teknik yang digunakan adalah teknik analisis deskriptif kualitatif dan analisis kuantitatif dengan bantuan program SPSS. 


\section{Jenis Data}

Sumber data yang dipakai dalam penelitian ini adalah data primer yang diperoleh dari hasil penelitian lapangan, melalui wawancara dengan menggunakan kuesioner dan pengamatan lapangan. Untuk data sekunder diperoleh dari berbagai sumber dan instansi yang mendukung penelitian, berupa informasi tentang kondisi fisik wilayah, kondisi kependudukan, kondisi ekonomi serta peta administrasi wilayah Kecamatan Koba.

\section{Teknik Pengumpulan Data}

\section{1.) Wawancara (interview)}

Menurut Stewart dan Cash dalam Haris Herdiansyah (2010), wawancara diartikan sebagai sebuah interaksi yang di dalamnya terdapat pertukaran atau berbagai aturan, tanggung jawab, perasaan, kepercayaan, motif, dan informasi. Pada teknik ini, peneliti mengadakan tatap muka dan berinteraksi tanya jawab langsung dengan pihak responden atau subjek untuk memperoleh data. Wawancara dalam penelitian ini khususnya dalam taraf permulaan, dilakukan secara tidak berstruktur.

Dalam penelitian ini penentuan sampel wawancara menggunakan teknik random sampling, yakni masing-masing kelurahan dipilih sebanyak 30 responden sehingga secara keseluruhan berjumlah 90 responden. Responden dipilih dengan latar belakang pekerjaan yang berbeda. Dari responden tersebut diteliti secara khusus beberapa informan pokok. Informan pokok yang dipilih adalah lurah atau perangkat kelurahan dan para pekerja tambang. Pertimbangannya adalah penelitian ini dimaksudkan juga untuk menganalisis perbedaan persepsi masyarakat yang terlibat langsung dengan kegiatan penambangan maupun yang tidak terlibat langsung dengan kegiatan penambangan.

\section{2.) Dokumentasi}

Menurut Herdiansyah (2010), studi dokumentasi adalah salah satu metode pengumpulan data kualitatif dengan melihat atau menganalisis dokumen-dokumen yang dibuat oleh subjek sendiri atau oleh orang lain tentang subjek Dalam penelitian ini, dokumentasi dilakukan dengan cara mengambil data statistik maupun dokumen perundang-undangan dan dokumen lainnya.

\section{Metode Analisis Data}

Teknik analisis data dalam penelitian ini menggunakan teknik analisis dengan model analisis deskriptif kualitatif untuk mengukur persepsi masyarakat akibat penambangan timah, dan teknik analisis statistik regresi berganda untuk mengetahui faktor-faktor yang dominan mempengaruhi persepsi masyarakat.

\section{PEMBAHASAN}

\section{Perkembangan dan Jenis Tambang}

Timah merupakan salah satu sumber daya alam yang menjadi andalan Pulau Bangka yang sudah ada sejak berabad-abad. Sejarah penemuan timah di Pulau Bangka dapat dilihat dari prasasti Kota Kapur yang merupakan salah satu saksi sejarah penemuan timah di Pulau Bangka dari tahun 686 yang dikuasai oleh kerajaan Sriwijaya pada waktu itu.

Seiring berkembangnya waktu, penambangan timah kemudian diambil alih oleh Pemerintah Negara Indonesia yang berstatus sebagai Badan Usaha Milik Negara (BUMN) yang bernama PT Timah Tbk. Perusahaan ini memiliki kuasa pertambangan yang hampir meliputi seluruh kawasan di Pulau Bangka. Seiring dengan perkembangan teknologi dan kemampuan masyarakat, kegiatan penambangan tidak hanya dilakukan oleh PT Timah Tbk., namun juga oleh pihak-pihak swasta maupun individu masyarakat yang lebih dikenal dengan nama "tambang inkonvensional" (TI). Kegiatan penambangan TI dilakukan dengan memanfaatkan peralatan mekanis sederhana yang bermodalkan Rp 10-15 Juta. Tambang inkonvensional sebenarnya kegiatan penambangan timah yang melanggar hukum karena pada umumnya para pelaku tidak memiliki izin yang sah untuk melakukan aktivitas penambangan.

Pada awal kemunculan, tambang inkonvensional dilakukan oleh para penambang atau pendulang yang diakomodasi oleh PT Tambang Timah yang kelak berubah menjadi PT Timah Tbk. Selaku perusahaan tambang milik negara, PT Tambang Timah melihat adanya titik-titik yang tidak ekonomis untuk dilakukan kegiatan penambangan oleh PT Tambang Timah. Pada saat itu peralatan pendulangan mekanis sederhana yang beroperasi di dalam areal kuasa penambangan PT Tambang Timah diberikan secara gratis kepada masyarakat untuk digunakan dalam proses pendulangan/penambangan timah. Akan tetapi, setelah masuk era Reformasi 1998, masyarakat mulai mencari-cari lokasi penambangan di luar lokasi kuasa penambangan PT Tambang 
Timah. Seiring waktu, penambangan TI itu berkembang pesat dan sukar dikontrol. Jumlah mereka ribuan, dan tidak berada di lokasi kuasa penambangan PT Tambang Timah.

Hingga 2015 pemerintah daerah Kabupaten Bangka Tengah telah mengeluarkan 64 Izin Usaha Penambangan (IUP) yang berada pada kawasan darat sesuai dengan Perda No. 39 Tahun 2011 tentang Pengelolaan Penambangan Mineral. Padahal, pada 2009, baru berjumlah 19 IUP yang dikeluarkan. Tampaknya setiap tahun pihak yang mendapatkan perizinan terus mengalami peningkatan, tanpa terkecuali setelah tahun 2015.

\section{Tabel 1: Perkembangan izin usaha pertambangan di Kabupaten Bangka Tengah}

\begin{tabular}{|ccccc|}
\hline Tahun & $\begin{array}{c}\text { Kontrak } \\
\text { Karya }\end{array}$ & $\begin{array}{c}\text { IUP PertambanganP } \\
\text { Eksporasi }\end{array}$ & KP2B \\
\hline 2009 & 1 & 12 & 7 & - \\
\hline 2010 & 1 & 5 & 56 & - \\
\hline 2011 & 1 & 2 & 56 & - \\
\hline 2012 & 1 & 4 & 60 & - \\
2013 & - & 3 & 60 & - \\
\hline 2014 & - & 3 & 60 & - \\
\hline 2015 & - & 4 & 60 & - \\
\hline
\end{tabular}

Sumber: Bangka Tengah dalam Angka, BPS, 2018

Proses kegiatan penambangan berskala kecil maupun besar tetap memiliki dampak (tingkat kerusakan lingkungan) yang berbeda beda. Semakin canggih dan modern metode penambangan yang digunakan, maka tingkat kerusakan lingkungan yang ditimbulkan akan semakin banyak karena skala penambangan yang semakin besar begitu juga dengan luas areal penambangan.

Adapun proses kegiatan penambangan di darat dapat dilaksanakan dengan beberapa metode penambangan, di antaranya adalah sebagai berikut:

1. Pendulangan (panning)

Pendulangan merupakan cara penambangan tradisional dengan kapasitas yang sangat sederhana sekali. Selain untuk pengambilan bijih timah, pendulangan ini juga biasanya dipakai untuk pengecekan/penentuan kadar timah dalam eksplorasi/pemboran, pengambilan sampel dan penentuan arah maju suatu penambangan. Walaupun cara yang dilakukan terbilang tradisional, sampai saat ini masih dipergunakan terutama untuk menambang eks tailing tambang/kapal keruk darat lama atau tanah asli yang dangkal (kurang dari dua meter) di pantai, umumnya untuk cadangan yang tidak ekonomis bilamana ditambang dengan tambang semprot ataupun tambang nonkonvensional. Penambangan dengan metode pendulangan meskipun dilaksanakan secara sederhana tetap dapat mengakibatkan kerusakan lingkungan walaupun dengan skala kerusakan yang tidak terlalu parah.

2. Tambang semprot (TS)

Tambang semprot adalah cara penambangan dengan pemberian tanah atas dan/atau tanah bertimah, kemudian dilakukan penyemprotan air bertekanan $( \pm 4 \mathrm{~atm})$ yang berasal dari pompa semprot hingga menjadi lumpur (pulp) campuran antara tanah dan air dengan perbandingan lebih kurang 1:10 yang kemudian dialirkan ke suatu sumuran (sump, camoy). Lumpur tersebut selanjutnya diisap dengan pompa tanah dan dialirkan ke instalasi pencucian (untuk tanah bertimah) atau ke luar front kerja (untuk tanah tak bertimah) yang dapat dimanfaatkan untuk back filling, menimbun bagian atas tailing, atau dipergunakan untuk pembuatan dam/phok siram dan lain-lain. Kedalaman yang ideal untuk tambang semprot bervariasi dari 4 sampai dengan 15 meter tergantung dari klasifikasi laju pemindahan tanahnya.

3. Tambang Nonkonvensional (TN)

Tambang nonkonvensional adalah tambang semprot dengan laju pemindahan tanah yang lebih kecil (20 $\left.\mathrm{m}^{3} / \mathrm{jam}\right)$. Cadangan yang dialokasikan untuk TN adalah cadangan dalam jumlah kecil. Cadangan itu berupa sisa tambang lama, cadangan tailing dengan kedalaman yang relatif lebih dangkal. Kekayaan cadangannya umumnya relatif tinggi dibandingkan dengan cadangan untuk TS, namun umur tambangnya relatif lebih singkat sehingga tidak ekonomis bila ditambang dengan TS. Peralatan yang digunakan umumnya mesin 
penggerak dengan pompa tanah dan pompa semprot tapi dengan daya yang relatif kecil.

4. Tambang Mekanik (TM)

Tambang mekanik adalah cara penambangan yang digunakan untuk cadangan timah kulit (cadangan $\mathrm{CO}$ yang diangkat kedalaman kurang dari 4 meter) dan letaknya jauh dari sumber air kerja. Tanah bertimah didorong dan dikumpulkan ke dalam bulldozer sebagai stockpile yang selanjutnya dimuatkan ke dalam dump truck dan diangkut ke instalasi pencucian yang diletakkan dekat dengan sumber air dan terpisah dari lokasi penambangan (umumnya dengan jarak kurang dari 3 meter).

5. Tambang Openpit (TO)

Tambang openpit adalah cara penambangan yang digunakan untuk cadangan timah primer (cadangan D), yakni lapisan timah yang umumnya berbentuk urat-urat timah dengan kekayaan yang relatif tinggi tapi tertutup dengan lapisan tanah penutup atau untuk cadangan alluvial dalam. Tambang openpit merupakan tambang mekanis dengan skala yang lebih besar, baik dari kapasitas pemindahan tanah, peralatan yang digunakan, maupun kedalaman tambang. Kedalaman tanah bisa mencapai puluhan sampai ratusan meter lebih sehingga harus dibuat trap-trap.

6. Tambang Bawah Tanah (underground mining)

Tambang bawah tanah adalah cara penambangan yang digunakan untuk menambang cadangan timah primer yang berbentuk urat dan dengan tanah penutup yang relatif tebal dan keras/kompak, serta tidak ekonomis jika ditambang dengan tambang openpit karena stripping ration yang terlalu besar. Untuk pembuatan terowongan, shaft atau penambangan urat biji umumnya harus dilakukan dengan peledakan; material hasil ledakan diangkut dengan lori, belt conveyor atau dump truck ke instalasi pengolahan di luar tambang bawah tanah (di permukaan) yang umumnya hampir sama dengan instalasi pencucian primer untuk biji dari tambang openpit.

\section{Kapal Isap (Cutter Suction Dredge)}

Kapal isap digunakan untuk penambangan cadangan alluvial yang terletak di sungai atau cadangan pantai pasang surut dangkal yang tidak dapat dikerjakan dengan kapal keruk. Lapisan tanah dipotong dengan pisau pemotong yang diputar dan diletakkan di ujung leader, kemudian diisap dengan pompa tanah dan dialirkan melalui rangkaian pipapipa ke instalasi pencucian.

\section{Karakteristik Masyarakat}

Melalui seleksi data primer terhadap 90 responden dari tiga kelurahan di Kabupaten Bangka Tengah, diperoleh gambaran tentang karakteristik masyarakat di daerah penelitian.

Karakteristik masyarakat di daerah penelitian dilihat dari beberapa faktor yang dijadikan sebagai indikator atau tolok ukur dalam penelitian ini, yakni tingkat pengetahuan masyarakat terhadap kegiatan penambangan timah, tingkat pendidikan masyarakat, daerah asal, pekerjaan masyarakat, pendapatan serta jumlah anggota rumah tangga masing-masing responden. Faktor tersebut diduga berpengaruh terhadap kerusakan lingkungan akibat penambangan timah.

\section{Pendidikan}

Tingkat pendidikan masyarakat merupakan salah satu faktor yang sering dijadikan tolok ukur dalam penelitian sosial dengan tinggi rendahnya tingkat pendidikan seseorang mampu membedakan pola pikir mereka dalam menyikapi suatu permasalahan, terutama yang menyangkut kepentingan banyak orang.

Dalam penelitian ini diketahui bahwa tidak ada responden yang tidak menamatkan pendidikan dasarnya, sebanyak 17,78 persen tingkat pendidikan masyarakat hanya sebatas pendidikan dasar, 20\% atau 18 orang menamatkan pendidikan sampai tingkat SLTP, sebanyak 42,22\% masyarakat menamatkan pendidikan sampai dengan SLTA dan sisanya sebanyak $20 \%$ bisa mengenyam pendidikan sampai dengan tingkat perguruan tinggi.

Berdasarkan tingkat pendidikan tersebut, bisa dilihat bahwa masyarakat sudah menyadari arti pentingnya pendidikan. Tinggi rendahnya pendidikan sangat berpengaruh terhadap pola pikir karena semakin banyak pengetahuan yang mereka miliki dari pendidikan, maka akan membawa suatu pikiran yang rasional dan logis dalam menyikapi sesuatu terhadap permasalahan di sekitarnya.

\section{Pekerjaan}

Banyaknya kesempatan kerja yang tersedia menyebabkan beraneka ragam pula jenis mata pencaharian masyarakat (responden). Peluang kerja yang tersedia di daerah penelitian di antaranya pegawai negeri sipil (PNS) guru sekolah negeri, karyawan swasta, buruh, pedagang/wiraswasta, petani, dokter, dan guru swasta.

Dari penelitian ini dapat diketahui bahwa pegawai (guru negeri dan karyawan swasta) berjumlah 37 orang, buruh sebanyak 23 orang, pedagang/wiraswasta sebanyak 18 orang, dan pekerjaan lainnya sebanyak 12 orang.

\section{Pendapatan}

Tingkat pendapatan masyarakat tentunya 
sangat tergantung dari jenis pekerjaan yang dimiliki. Berdasarkan hasil survei lapangan didapatkan informasi bahwa pendapatan terendah masyarakat sebesar Rp 500.000, dan pendapatan tertinggi sebesar Rp 4.500.000. Sebanyak 67\% masyarakat berpenghasilan Rp 500.000 hingga Rp 1.650.000; sebanyak 30\% masyarakat berpenghasilan Rp. 1.650.000 hingga Rp 3.050.000; sebanyak 3\% masyarakat berpenghasilan Rp 3.050.000 hingga Rp. 4.500.000.

Adanya kegiatan penambangan, khususnya TI, membuat semakin mudahnya masyarakat mendapatkan penghasilan, namun tentu saja jika kandungan biji timahnya tersedia di lokasi tambang. Masyarakat yang berprofesi sebagai pelaku tambang dapat dengan mudah mengeruk keuntungan yang lebih dikarenakan mudahnya mendapatkan penghasilan dari kegiatan penambangan.

\section{Jumlab anggota rumah tangga}

Jumlah anggota keluarga dalam suatu rumah tangga juga dapat dijadikan indikasi terhadap persepsi masyarakat. Selain itu, dengan melihat jumlah anggota rumah tangga, kita dapat memperkirakan bahwa masyarakat tersebut dalam memperhatikan kesejahteraan anggota keluarganya sudah tinggi. Jumlah anggota keluarga disesuaikan dengan kemampuan ekonomi sehingga kesejahteraan keluarga dapat terjamin. Pengategorian jumlah anggota keluarga pada penelitian ini didasarkan pada konsep caturwarga dalam keluarga berencana dengan sebanyak 48 orang responden memiliki lebih dari 4 anggota keluarga (sebanyak $48 \%$ ), dan 42 orang (47\%) kurang dari 4 anggota keluarga.

\section{Daerah asal}

Sebagai suatu daerah yang terdapat di provinsi yang tergolong baru terbentuk, dan dengan peluang mendapatkan kesempatan kerja tergolong cukup banyak, masyarakat di daerah penelitian tidak hanya berasal dari masyarakat lokal/pribumi tapi banyak juga para pendatang dari berbagai daerah, baik dari luar Kabupaten Bangka Tengah maupun dari luar Provinsi Kepulauan Bangka Belitung. Pada penelitian ini diketahui bahwa sebanyak 43 orang (47,78\%) berasal dari Kabupaten Bangka Tengah; sebanyak 18 orang (20\%) berasal dari luar Kabupaten Bangka Tengah tapi masih bagian dari Provinsi Bangka Belitung; sisanya sebanyak 29 orang $(32,22 \%)$ berasal dari luar Provinsi Bangka Belitung.

6. Pengetabuan masyarakat tentang kegiatan penambangan timab

Dari pengamatan di lapangan, diketahui bahwa pengetahuan masyarakat terhadap kegiatan penambangan timah tergolong tinggi seperti tampak pada gambar 3 di bawah ini.

Tabel 2: Tingkat Pengetahuan masyarakat terhadap pertambangan timah

\begin{tabular}{|clcc|}
\hline Interval & Kategori hierarki & Jumlah (orang) & Persentase \\
$9-15$ & Rendah & 1 & 1,11 \\
$16-21$ & Sedang & 18 & 20,00 \\
$22-27$ & Tinggi & 71 & 78,89 \\
& total & 90 & 100,00 \\
\hline
\end{tabular}

Sumber: Pengolahan data primer

Berdasarkan tabel 2 di atas diketahui bahwa pada dasarnya masyarakat Pulau Bangka, khususnya masyarakat di daerah penelitian, sudah mengetahui adanya kegiatan penambangan timah, baik yang dilakukan oleh perusahaan maupun pihak swasta/masyarakat. Sebanyak $83,34 \%$ masyarakat mengetahui adanya kegiatan penambangan rakyat yang lebih dikenal dengan TR (Tambang Rakyat) atau TI (Tambang Inkonvensional) dengan melihat langsung di lapangan.

Di daerah penelitian, kegiatan penambangan timah banyak terdapat di lingkungan bemban untuk Desa Nibung, lingkungan Marbuk (eks KobaTin) untuk Kelurahan Berok, dan lingkungan Jungkung Kelurahan Simpang Perlang. Berdasarkan data primer lapangan, sebanyak 54,44\% masyarakat di daerah penelitian kurang mengetahui cara-cara atau sistem penambangan timah. Dari sekian banyaknya metode penambangan, mereka lebih mengenal penambangan dengan sistem terbuka dan penambangan hidrolik.

Survei lapangan yang dilakukan juga menunjukkan bahwa sekitar 85,56\% masyarakat (responden) mengetahui berbagai konsekuensi logis dari kegiatan penambangan timah tersebut, dan semua itu dapat diketahui dengan melihat langsung di lapangan, namun ada juga responden yang mengetahuinya lewat media massa. 
Tabel 3: Indikator Pengetahuan masyarakat t

\begin{tabular}{|llcccccc|}
\hline & \multicolumn{5}{c|}{ Tingkat Pengetahuan } \\
\hline No. & \multicolumn{1}{c|}{ Indikator } & \multicolumn{3}{c|}{ Tidak Tahu } & Kurang Tahu & Tahu \\
& & Jumlah & $\%$ & Jumlah & $\%$ & Jumlah & $\%$ \\
\hline 1. & Adanya kegiatan penambangan timah & 0 & 0 & 8 & 8,89 & 82 & 9,11 \\
\hline 2. & Lokasi penambangan & 0 & 0 & 32 & 35,56 & 58 & 64,44 \\
\hline 3. & Kerusakan lingkungan akibat penambangan & 0 & 0 & 13 & 14,44 & 77 & 85.56 \\
\hline 4. & Jenis-jenis kerusakan lingkungan & 0 & 0 & 19 & 21,11 & 71 & 78,89 \\
\hline 5. & Cara/sistem penambangan timah & 4 & 4,44 & 49 & 54,44 & 37 & 41,12 \\
\hline 6 & Alat-alat yang digunakan untuk penambangan & 3 & 3,33 & 44 & 48,89 & 43 & 47,78 \\
\hline
\end{tabular}

Sumber: Hasil analisis data primer

\section{Persepsi Masyarakat terhadap Kerusakan Lingkungan akibat Penambangan limah}

Hasil pengolahan data lapangan diketahui bahwa persepsi masyarakat terhadap kerusakan lingkungan akibat penambangan timah tergolong sedang. Hal ini dapat diartikan bahwa masyarakat, dalam hal ini responden, beranggapan positif dan setuju jika kegiatan penambangan timah terutama Tambang Inkonvensional menimbulkan dampak-dampak negatif, terutama dampak berupa kerusakan lingkungan. Walaupun demikian, masyarakat juga tidak memungkiri bahwa kegiatan penambangan tersebut dapat memberikan dampak positif terhadap peningkatan perekonomian dalam hal pendapatan masyarakat.

\section{Gambar 2: Persepsi Masyarakat}

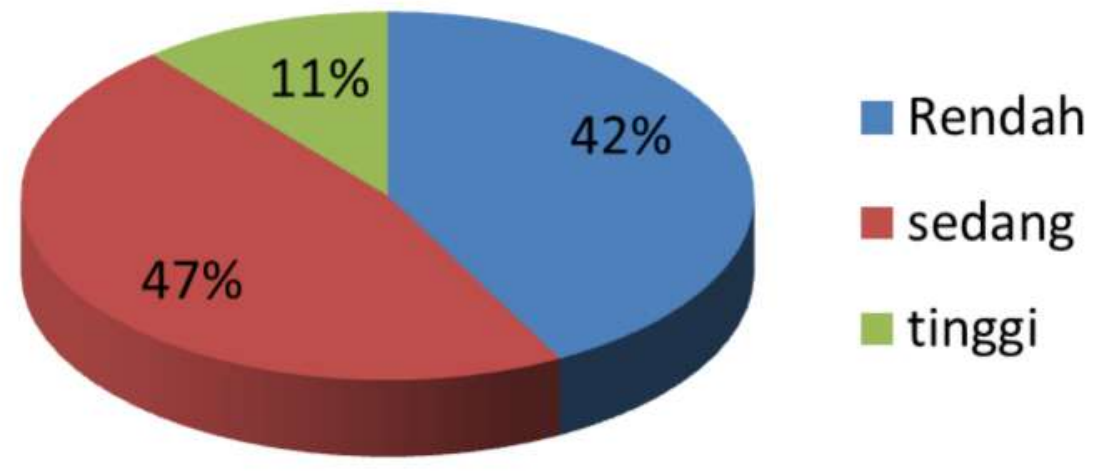

Penggolongan kategori tingkat persepsi masyarakat terhadap kerusakan lingkungan penambangan timah didasarkan dengan metode skoring. Rata-rata skor persepsi masyarakat dari responden sebanyak 90 orang sebesar 58,87 dengan standard error sebesar 0,407 . Hal ini bisa ditafsirkan rentang rata-rata skor persepsi masyarakat terletak pada 57,649 sampai 60,091 dengan standard deviasi 3.

\section{Persepsi masyarakat ditinjau dari aspek pengetahuan}

Ditinjau dari aspek pengetahuan, mereka yang memiliki tingkat pengetahuan tinggi tentang kegiatan penambangan timah, maka memiliki persepsi yang bervariasi terhadap kerusakan lingkungan yang diakibatkan kegiatan penambangan timah. Dari hasil tabulasi silang diketahui bahwa walaupun tingkat pengetahuan masyarakat tergolong tinggi tapi tingkat persepsi terhadap kerusakan lingkungan rendah. Hal ini menandakan bahwa pada dasarnya mereka kurang peduli terhadap keadaan lingkungan sekitar mereka yang rusak.

Tabel 4. Tabulasi silang persepsi dan pengetahuan

\begin{tabular}{|lcccc|}
\hline & \multicolumn{4}{c|}{ Klasifikasi Pengetahuan } \\
\hline Klasifikasi Rendah & 1 & 3 & 34 & 38 \\
\hline Persepsi Sedang & 0 & 11 & 31 & 42 \\
\hline Tinggi & 0 & 4 & 6 & 10 \\
\hline Total & 1 & 18 & 71 & 90 \\
\hline
\end{tabular}

Sumber: pengolahan data primer 
2. Persepsi masyarakat ditinjau dari aspek jumlah rumah tangga

Ditinjau dari aspek jumlah rumah tangga, mereka yang jumlah anggota rumah tangganya terdiri atas lebih dari 4 anggota rumah tangga cenderung memiliki tingkat persepsi yang rendah, sedangkan mereka yang anggota rumah tangganya kurang dari 4 anggota cenderung klasifikasi persepsinya sedang.

Tabel 5. Tabulasi silang persepsi dan jumlah rumah tangga

\begin{tabular}{|lllc|} 
& \multicolumn{4}{c}{ Jumlah Anggota Rumah Tangga } \\
\hline & $\mathbf{1}$ & $\mathbf{2}$ & total \\
Klasifikasi Rendah & 20 & 18 & 38 \\
Persepsi Sedang & 19 & 23 & 42 \\
$\quad$ Tinggi & 9 & 1 & 10 \\
Total & 48 & 42 & 90 \\
\hline
\end{tabular}

Keterangan

$1 . \leqslant 4$

2. $\geqslant 4$

Sumber: Pengolahan data primer

3. Persepsi masyarakat ditinjau dari aspek pendidikan

Ditinjau dari aspek pendidikan, mereka yang memiliki tingkat pendidikan tinggi (perguruan tinggi) mempunyai persepsi sedang terhadap kerusakan lingkungan akibat penambangan timah. Kebanyakan dari mereka yang tingkat pendidikannya SLTA justru memiliki persepsi rendah dan tinggi. Hal ini menandakan bahwa masyarakat dengan berbagai variasi tingkat pendidikan memiliki persepsi yang berbeda dalam menilai kerusakan lingkungan yang terjadi akibat penambangan timah.

Tabel 6. Tabulasi silang persepsi dan pendidikan

\begin{tabular}{|c|c|c|c|c|c|c|}
\hline & & & \multicolumn{3}{|c|}{ Pekerjaan } & \multirow[t]{2}{*}{ Total } \\
\hline & & SD & SLTP & SLTA & PT & \\
\hline Klasifikasi & Rendah & 7 & 6 & 21 & 4 & 38 \\
\hline Persepsi & Sedang & 9 & 12 & 11 & 10 & 42 \\
\hline Tingg & & 0 & 0 & 6 & 4 & 10 \\
\hline Total & & 16 & 18 & 38 & 18 & 90 \\
\hline
\end{tabular}

Sumber: Pengolahan data primer

\section{Persepsi masyarakat ditinjau dari aspek pekerjaan}

Ditinjau dari aspek pekerjaan, mereka yang memiliki klasifikasi persepsi rendah adalah mereka yang memiliki mata pencaharian sebagai buruh. Fakta ini dinilai wajar dikarenakan kebanyakan dari buruh tersebut terlibat langsung dengan kegiatan penambangan sehingga mereka cenderung memperhatikan kepentingan ekonomi. Meskipun demikian, masyarakat dengan berbagai variasi pekerjaan memiliki persepsi yang berbeda dalam menilai kerusakan lingkungan yang terjadi akibat penambangan timah.

Tabel 7. Tabulasi silang persepsi dan pekerjaan

\begin{tabular}{|c|c|c|c|c|c|c|c|}
\hline & & \multicolumn{4}{|c|}{ Pekerjaan } & \multicolumn{2}{|r|}{ Total } \\
\hline & & \multirow{2}{*}{$\begin{array}{c}\text { Pegawai } \\
\text { (guru PNS, dan } \\
\text { karyawan swasta) } \\
14\end{array}$} & \multicolumn{2}{|c|}{$\begin{array}{c}\text { Buruh } \\
\text { (bangunan, pekerja TI, } \\
\text { buruh harian) }\end{array}$} & \multirow[t]{2}{*}{$\begin{array}{l}\text { Pedagang/ } \\
\text { wiraswasta }\end{array}$} & \multicolumn{2}{|c|}{$\begin{array}{c}\text { Profesi lain } \\
\text { (apoteker, dokter, petani) }\end{array}$} \\
\hline Klasifikasi & Rendah & & 16 & 4 & & 4 & 38 \\
\hline Persepsi & Sedang & 16 & 6 & 13 & & 7 & 42 \\
\hline Tinggi & & 7 & 1 & 1 & & 1 & 10 \\
\hline Total & & 37 & 23 & 18 & & 12 & 90 \\
\hline
\end{tabular}

Sumber: Pengolahan data primer

\section{Persepsi masyarakat ditinjau dari aspek daerah asal}

Ditinjau dari aspek daerah asal, sebanyak 43 responden berasal dari Kabupaten Bangka Tengah. Sebanyak 18 responden berasal dari luar Kabupaten Bangka tapi masih di dalam Provinsi Bangka Belitung, dan sebanyak 29 responden berasal dari luar Provinsi Bangka Belitung. Responden memiliki variasi persepsi dalam 
menilai kerusakan lingkungan yang terjadi akibat penambangan timah. Namun demikian, kebanyakan dari responden memiliki persepsi sedang.

Tabel 8. Tabulasi silang persepsi dan daerah asal

\begin{tabular}{|c|c|c|c|c|}
\hline & \multicolumn{2}{|c|}{ Daerah Asal } & & \multirow[t]{2}{*}{ Total } \\
\hline & Kab. Bateng & $\begin{array}{l}\text { Luar Kab. Bateng } \\
\text { dalam Prov. Babel }\end{array}$ & Luar Prov. Babel & \\
\hline Klasifikasi Rendah & 18 & 7 & 13 & 38 \\
\hline Persepsi Sedang & 18 & 8 & 16 & 42 \\
\hline Tinggi & 7 & 3 & 0 & 10 \\
\hline Total & 43 & 18 & 29 & 90 \\
\hline
\end{tabular}

Sumber: Pengolahan data primer

6. Persepsi masyarakat ditinjau dari aspek pendapatan

Ditinjau dari aspek pendapatan, kebanyakan responden memiliki klasifikasi persepsi sedang dalam melihat kerusakan lingkungan akibat kegiatan penambangan timah.

Tabel 9. Tabulasi silang persepsi dan pendapatan

\begin{tabular}{|c|c|c|c|c|c|}
\hline & & \multicolumn{3}{|c|}{ Pendapatan } & \multirow[t]{2}{*}{ Total } \\
\hline & & 1 & 2 & 3 & \\
\hline Klasifikasi & Rendah & 25 & 12 & 1 & 38 \\
\hline \multirow[t]{2}{*}{ Persepsi } & Sedang & 29 & 12 & 1 & 42 \\
\hline & Tinggi & 6 & 3 & 1 & 10 \\
\hline Total & & 60 & 27 & 3 & 90 \\
\hline
\end{tabular}

keterangan

1. Rp 500.000 - Rp 1.650 .000

2. Rp $1.650 .000-\operatorname{Rp} 3.050 .000$

3. Rp $3.050 .000-\operatorname{Rp} 4.500 .000$

Sumber: Pengolahan data primer

Berdasarkan beberapa pengolahan data primer di atas, peneliti menggunakan SPSS untuk mengetahui faktor yang berpengaruh terhadap persepsi masyarakat terhadap kerusakan lingkungan. Dari keenam faktor ternyata hanya tiga faktor yang bisa diolah datanya, yakni faktor pendidikan, pengetahuan dan pendapatan. Adapun faktor jumlah rumah tangga, pekerjaan, dan daerah asal setelah diolah ternyata hasilnya tidak keluar. $\mathrm{Hal}$ ini mungkin disebabkan oleh distribusi dari ketiga data tersebut. Angka $\mathrm{R}$ menunjukkan korelasi/hubungan antara variabel pengaruh dengan variabel terpengaruh, sedangkan angka $\mathrm{R}$ square menunjukkan proporsi sumbangan variabel-variabel pengaruh secara bersama-sama terhadap variabel terpengaruh.

Tabel 10. Pengaruh variabel independen terhadap variabel dependen

\begin{tabular}{|llll|}
\hline Variabel Independen & R & R Square & Sig \\
\hline Pendidikan & 0,209 & 0,044 & 0,048 \\
\hline Pendapatan & 0,231 & 0,053 & 0,028 \\
\hline Pengetahuan & 0,243 & 0,059 & 0,021 \\
\hline Total & & 15,6 & \\
\hline
\end{tabular}

Sumber: Pengolahan data primer 
Berdasarkan total R Square untuk tiga variabel tersebut, diketahui bahwa sebanyak 15,6\% terdiri atas 4,4\% persepsi masyarakat dipengaruhi oleh faktor pendidikan, sebanyak 5,3\% dipengaruhi oleh faktor pendapatan, dan sebanyak 5,9\% dipengaruhi oleh faktor pengetahuan. Adapun sebanyak $84,4 \%$ lainnya dipengaruhi oleh faktor seperti daerah asal, jumlah anggota keluarga, dan pekerjaan.

Berdasarkan R Square dapat diketahui bahwa variabel/faktor yang paling berpengaruh terhadap persepsi masyarakat terhadap kerusakan lingkungan adalah tingkat pengetahuan masyarakat terhadap kegiatan penambangan timah, yaitu sebesar 5,9\%. Hal ini dapat dikarenakan bahwa dengan tingkat pengetahuan yang dimiliki masyarakat tentang kegiatan penambangan, masyarakat tentunya mengetahui segala dampak yang ditimbulkan atas kegiatan tersebut.

\section{KESIMPULAN}

Berdasarkan hasil penelitian dapat disimpulkan beberapa pernyataan sebagai berikut:

1. Keberadaan pertambangan timah sangat berkaitan erat dengan potensi lahan galian di suatu wilayah. Berbagai usaha mulai dari usaha pencarian dan pembuktian, penggalian, pengolahan dan pemurnian, serta pemasaran telah dilakukan oleh perusahaan pertambangan timah milik pemerintah maupun swasta. Bila dilihat dari semakin luasnya lokasi penambangan, hal tersebut sudah berlangsung sangat lama dan berkembang dengan cepat.

2. Pendidikan, pendapatan, dan pengetahuan terhadap kegiatan penambangan menjadi faktor yang berpengaruh terhadap persepsi masyarakat terhadap kerusakan lingkungan akibat kegiatan penambangan timah. Dari ketiga faktor tersebut, pengetahuan merupakan faktor yang paling berpengaruh terhadap persepsi masyarakat.

3. Pada umumnya masyarakat di daerah penelitian sangat mengetahui tentang kegiatan penambangan timah, baik masyarakat yang tidak terlibat langsung ataupun yang terlibat langsung dengan kegiatan penambangan. Pasalnya adalah kegiatan tersebut dapat ditemui hampir di setiap daerah dan wilayah di Pulau Bangka. Hampir setiap masyarakat di daerah penelitian pernah melihat langsung kegiatan penambangan timah di lapangan sehingga mereka telah tahu proses penambangan timah.

\section{DAFTAR PUSTAKA}

Badan Pusat Statistik. (2018). Perkembangan Izin Usaba Pertambangan 2009-2015. Kabupaten Bangka Tengah, Bangka Belitung

Baiquni, M., dan Susilawardani. (2002). Pembangunan yang Tidak Berkelanjutan: Refleksi Kritis Pembangunan Indonesia. Yogyakarta: ideAs dan Transmedia Global wacana

Bintarto. (1984). Urbanisasi dan Permasalabannya. Jakarta: Ghalia Indonesia

Direktorat Tata Lingkungan Geologi dan Kawasan Pertambangan. (2002). Evaluasi Geologi Lingkungan Lahan Bekas Tambang Kawasan Pertambangan Kabupaten Bangka Propinsi Bangka Belitung. Bandung

Hafid, Achmad. (1995). Pertambangan Umum. Bangka: PT. Tambang Timah Persero

Hardjasoemantri, Koesnadi. (1992). Hukum Tata Lingkungan. Yogyakarta: Gadjah Mada University Press

Henny. (2007). "Persepsi Masyarakat terhadap Kerusakan Lingkungan akibat Penambangan Timah di Kecamatan Sungailiat, Kabupaten Bangka”. Tesis. Yogyakarta: Universitas Gadjah Mada

Herdiansyah, Haris. (2010). Metode Penelitian Kualitatif untuk Ilmu-ilmu Sosial. Jakarta: Salemba Humanika

Mustar, Djunaidi. (1996). Pertambangan Umum. Bangka: PT. Tambang Timah Persero

Perda Kabupaten Bangka Tengah Nomor 39 Tahun 2011 tentang pengelolaan penambangan Mineral

Ritohardoyo, Su. (1995). Ekologi Manusia. Diktat Kuliah S-2 Ilmu Lingkungan UGM. Yogyakarta

Ritohardoyo, Su. (2006). Ekologi Manusia. Diktat Kuliah S-2 Ilmu Lingkungan UGM. Yogyakarta

Simatupang, M, dan S. Sigit. (1992). Pengantar Pertambangan Indonesia. Jakarta: Asosiasi Pertambangan Indonesia

Soemarwoto. (2001). Ekologi, Lingkungan Hidup, dan Pembangunan. Jakarta: Djambatan

Sujitno, Sutedjo. (1986). Sejarab Timah Indonesia. Bangka: PT. Timah Tbk

Walgito, Bimo. (1999). Psikologi Sosial: Suatu Pengantar. Yogyakarta: Andi Offset 
